Niken Dyah Ayu KD, Rizal dan Hariadi S, Analisis Program Penyuluhan, Sumber Daya Manusia Pada Optimalisasi IB Dan Sarana Prasarana Perluasan Lahan HMT Terhadap Peningkatan Produksi Sapi Potong Di Kabupaten Bondowoso

\title{
ANALISIS PROGRAM PENYULUHAN, SUMBER DAYA MANUSIA PADA OPTIMALISASI IB DAN SARANA PRASARANA PERLUASAN LAHAN HMT TERHADAP PENINGKATAN PRODUKSI SAPI POTONG DI KABUPATEN BONDOWOSO
}

\author{
(The analysis extension program, optimization human resources of Artificial Insemination (AI) and \\ expansion infrastructure to forage of beef cattle production increase in Bondowoso )
}

Oleh :

\begin{abstract}
NIKEN DYAH AYU KUSUMA DEWI *), RIZAL dan HARIADI SUBAGJA **)
\end{abstract}
\begin{abstract}
ABSTRAK
Penelitian ini bertujuan 1) menganalisis pengaruh program penyuluhan terhadap peningkatan produksi sapi potong di Kabupaten Bondowoso, 2) menganalisis pengaruh sumber daya manusia pada optimalisasi IB terhadap peningkatan produksi sapi potong di Kabupaten Bondowoso, 3) menganalisis pengaruh sarana prasarana perluasan lahan HMT terhadap peningkatan produksi sapi potong di Kabupaten Bondowoso. Populasi yang dalam penelitian ini adalah petani sapi potong yang berjumlah 250 orang di Kabupaten Bondowoso. Penelitian ini menggunakan ukuran sampel 160 orang. Metode analisis data menggunakan Structural Equation Model (SEM). Hasil penelitian menunjukkan program penyuluhan berpengaruh positif signifikan terhadap peningkatan produksi sapi potong di Kabupaten Bondowoso. Sumber daya manusia Optimalisasi IB (Inseminasi Buatan) berpengaruh positif signifikan terhadap peningkatan produksi sapi potong di Kabupaten Bondowoso. Sarana prasarana perluasan lahan HMT (Hijauan Makanan Ternak) tidak berpengaruh positif signifikan terhadap peningkatan produksi sapi potong di Kabupaten Bondowoso.
\end{abstract}

Kata kunci: produksi sapi potong, perluasan lahan, program penyuluhan, sumber daya manusia

\begin{abstract}
This study was intended to analyze 1) the effect of extension program on beef cattle production increase in Bondowoso, 2) the effect of influence optimization human resources of Artificial Insemination on beef cattle production increase in Bondowoso, 3) the effect of expansion infrastructure to forage on beef cattle production increase in Bondowoso. The population in this study was all beef cattle farmers were 250 in total. This study involved 160 beef cattle farmers as sample. The analysis tool used in this study was the Structural Equation Model (SEM). The results showed that extension program and influence optimization human resources of Artificial Insemination significantly and positive effects on beef cattle production increase in Bondowoso, but expansion infrastructure to forage had no significantly and positive effect on beef cattle production increase in Bondowoso
\end{abstract}

Keywords: beef cattle production, expansion infrastucutre, extension programs, human resources

\section{PENDAHULUAN}

Pembangunan pertanian salah satunya di titik beratkan pada pembangunan peternakan sebagai penyedia protein hewani, bahan baku industri makanan siap saji, penyerapan tenaga kerja dan investasi permodalan. Peranan peternakan cukup potensial untuk meningkatkan kesejahteraan masyarakat melalui pengembangan dan pemanfaatan sumber daya yang dimiliki setiap daerah. Ketersediaan sumber daya ternak dan peternak, lahan berbagai jenis pakan hijauan, serta ketersediaan inovasi teknologi pongolahan menjadi modal yang kuat untuk memenuhi kebutuhan konsumsi daging bagi bangsa Indonesia, bahkan berpotensi menjadi eksportir produk peternakan. Jika potensi lahan yang ada dapat dimanfaatkan $50 \%$ saja maka jumlah ternak yang dapat ditampung mencapai 29 juta satuan ternak (ST). Belum lagi kalau padang rumput alam yang ada diperbaiki dan ditingkatkan kualitasnya dengan menggunakan rumput unggul sehingga daya tampungnya meningkat secara nyata (Bamualim $e t$ al. 2008).

Kebutuhan daging sapi terus meningkat seiring makin baiknya kesadaran masyarakat akan pentingnya gizi yang seimbang, pertambahan 
penduduk, dan meningkatnya daya beli masyarakat. Salah satu upaya untuk memenuhi kebutuhan daging dalam negeri yaitu dengan meningkatkan populasi, produksi, dan produktivitas sapi potong. Indonesia dengan jumlah penduduk hampir 223 juta orang dengan laju pertumbuhan $1.01 \%$ /tahun merupakan pasar potensial bagi produk peternakan. Volume impor sapi potong dan produk olahannya cukup besar, setara dengan 600-700 ekor/tahun. Potensi tersebut belum tergarap maksimal untuk memenuhi kebutuhan daging sapi. Ketersediaan dalam memenuhi konsumsi tersebut diperoleh dari pemotongan ternak sapi dan kerbau lokal dari sentra produksi: Jawa Barat, Banten, NTT, NTB, Bali, Jawa Timur, Jawa Tengah, DIY, Jawa Barat, Lampung dan Sulawesi Selatan. Meskipun masih terjadi kekurangan penyediaan konsumsi yang harus dicukupi melalui impor sapi bakalan dan daging beku terutama dari Australia dan New Zealand.

Propinsi Jawa Timur pada tahun 2011sebagai salah satu lumbung sapi potong di Indonesia dengan populasi sapi dan kerbau sebanyak 5.05 juta ekor. Sedangkan kenyataannya pada Tahun 2013 populasi sapi dan kerbau turun $24.2 \%$ menjadi 3.83 juta ekor, bahkan penurunan populasi sapi potong ini juga terjadi di Kabupaten Bondowoso.

Program peningkatan produksi hasil peternakan menetapkan target sebagai tolak ukur kinerja program, namun dalam implementasi program tersebut ada beberapa ketidak sesuaian antara target dan realisasi pencapaian.

Program pemerintah Kabupaten Bondowoso dalam Peningkatan Produksi hasil Peternakan khususnya ternak sapi potong dilakukan melalui beberapa kebijakan yang berupa : (1) Program penyuluhan pendampingan bagi petani ternak; (2) Dukungan sumber daya manusia pada kegiatan optimalisasi IB (Inseminasi Buatan); dan (3) Sarana prasarana perluasan lahan HMT (Hijauan Makanan Ternak). Namun dari beberapa program yang dilakukan tersebut belum berjalan optimal, sehingga ; kendala yang timbul pada peternakan sapi potong di Kabupaten Bondowoso sangat penting dilakukan penelitian analisis pengaruh program penyuluhan, sumber daya manusia pada optimalisasi IB dan sarana prasarana perluasan lahan HMT terhadap peningkatan produksi sapi potong di Kabupatem Bondowoso.

Rumusan masalah penelitian antara lain: 1) Apakah terdapat pengaruh positif signifikan pada variabel program penyuluhan terhadap peningkatan produksi sapi potong di Kabupaten Bondowoso, 2) Apakah terdapat pengaruh positif signifikan pada variabel sumber daya manusia pada optimalisasi IB terhadap peningkatan produksi sapi potong di Kabupaten Bondowoso, 3) Apakah terdapat pengaruh positif signifikan pada variabel saran prasarana perluasan lahan HMT terhadap peningkatan produksi sapi potong di Kabupaten Bondowoso.

Penelitian ini dilakukan dengan tujuan: 1) Menganalisis pengaruh program penyuluhan terhadap peningkatan produksi sapi potong di Kabupaten Bondowoso, 2) Menganalisis pengaruh sumber daya manusia Optimalisai IB terhadap peningkatan produksi sapi potong di Kabupaten Bondowoso, 3) Menganalisis pengaruh sarana prasarana perluasan lahan HMT terhadap peningkatan produksi sapi potong di Kabupaten Bondowoso.

Penelitian ini memiliki beberapa hipotesis antara lain: 1) Program penyuluhan (X1) berpengaruh positif signifikan terhadap peningkatan produksi sapi potong (Y1) di Kabupaten Bondowoso, 2) Sumber daya manusia optimalisasi IB (X2) berpengaruh positif signifikan terhadap peningkatan produksi sapi potong (Y1) di Kabupaten Bondowoso, 3) Sarana prasarana perluasan lahan HMT (X3) berpengaruh positif signifikan terhadap peningkatan produksi (Y1) di Kabupaten Bondowoso

Ruang lingkup penelitian ini dilakukan pada populasi peternak sapi potong di Kabupaten Bondowoso yang berjumlah 250 orang, menggunakan sampel sebanyak 160 responden berdasarkan Random Sampling. variabel penelitian meliputi pengaruh program penyuluhan pendampingan bagi petani ternak, dukungan sumber daya manusia pada kegiatan optimalisasi IB (Inseminasi Buatan) dan fasilitas sarana prasarana perluasan lahan HMT (Hijauan Makanan Ternak) terhadap peningkatan produksi sapi potong. Alat analisis menggunakan SEM (Structural Equation Research). Hasil penelitian diharapkan memperoleh implikasi manajerial bagi pengambilan kebijakan dalam peningkatan produksi sapi potong

\section{METODE PENELITIAN}

Penelitian ini termasuk dalam penelitian penjelasan (explanatory research) yang menganalisis variabel penelitian berdasarkan indikator-indikator dimensional yang paling dominan. Penelitian juga termasuk konfirmatory (confirmatory reseach) yang mengkonfirmasikan hasil penelitian melalui implikasi manajerial. Jenis dan sumber data menggunakan data primer yang diperoleh langsung dari responden dan data sekunder yang diperoleh dari lembaga penelitian maupun dinas atau instansi yang berkaitan dengan penelitian.

Lokasi penelitian dilaksanakan di sentra populasi petani ternak sapi potong di Kabupaten 
Niken Dyah Ayu KD, Rizal dan Hariadi S, Analisis Program Penyuluhan, Sumber Daya Manusia Pada Optimalisasi IB Dan Sarana Prasarana Perluasan Lahan HMT Terhadap Peningkatan Produksi Sapi Potong Di Kabupaten Bondowoso

Bondowoso yang berjumlah 250 orang. Penelitian ini menggunakan jumlah sampel sebesar 160 responden. Teknik pengambilan sampel dalam penelitian menggunakan random sampling karena populasi mempunyai anggota atau unsur yang homogen.

Variabel penelitian yang digunakan dalam analisa data berdasarkan penilaian terhadap variable eksogen (Program penyuluhan, sumber daya manusia optimalisasi IB dan sarana prasarana perluasan lahan HMT) dan variable endogen (produksi sapi potong) yang diperoleh berdasarkan pernyataan kuisioner responden melalui beberapa indicator. Kerangka pemikiran penelitian dapat dijsajikan pada Gambar 1.

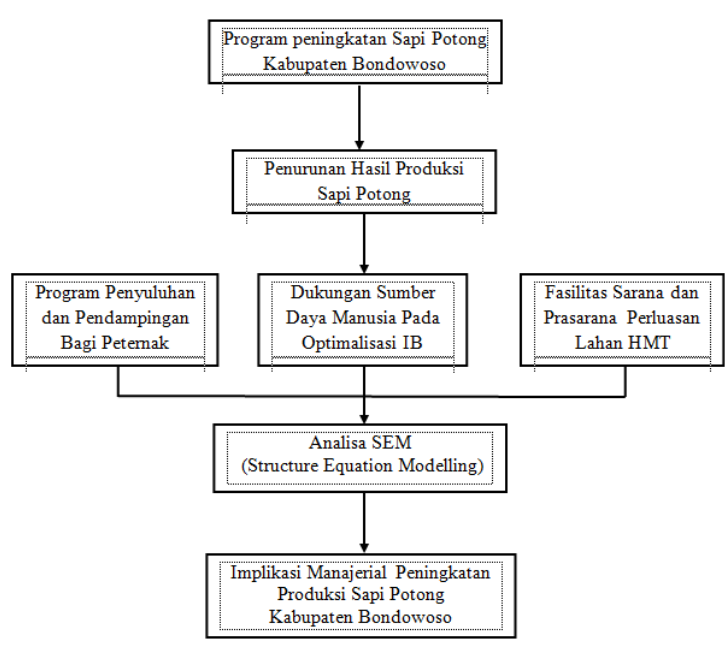

Gambar 1 Kerangka Pemikiran Penelitian

Definisi operasional variable penelitian yang dilakukan analisa berdasarkan penilaian terhadap variable eksogen (Program penyuluhan, sumber daya manusia pada optimalisasi IB dan sarana prasarana perluasan lahan HMT) dan variable endogen (produksi sapi potong) yang diperoleh berdasarkan pernyataan kuisioner responden melalui beberapa indikator, meliputi :

\section{Program penyuluhan dan pendampingan bagi petani ternak (X1)}

Indikator variable program penyuluhan meliputi : Pengembangan perilaku inovatif, Penguatan partisipasi petani, Penguatan kelembagaan petani, Penguatan akses terhadap berbagai sumber daya, Penguatan kemampuan petani berjaringan, dan kaderisasi. (Marliati et al 2008).

1. Pengembangan perilaku inovatif (X1.1)
Kinerja penyuluh dalam meningkatkan pengetahuan, keterampilan, sikap dan adopsi inovasi peternak pada program peningkatan produksi sapi potong

2. Penguatan partisipasi petani ternak sapi potong (X1.2)

Kinerja penyuluh membantu/ memfasilitasi petani mengidentifikai kebutuhannya, melibatkan petani dalam proses perencanaan, pelaksanaan dan evaluasi program penyuluhan dalam peningkatan produksi sapi potong.

3. Penguatan kelembagaan petani ternak sapi potong (X1.3)

Kinerja penyuluh memanfaatkan potensi kelembagaan petani yang berakar kuat dari dalam masyarakat, memotivasi/ memfasilitasi kerjasama dan dinamika kelompok dalam upaya peningkatan produksi sapi potong.

4. Penguatan akses terhadap berbagai sumber daya (X1.4)

Kinerja penyuluh memotivasi/ memfasilitasi petani menemukan/ memanfaatkan inovasi, kemudahan mendapatkan/ menyediakan sarana produksi yang berkualitas, modal usaha, teknologi pertanian spesifik lokasi, pemasaran yang menguntungkan dan akses teknologi pengolahan hasil pertanian dalam program peningkatan produski sapi potong.

5. Penguatan kemampuan petani ternak sapi potong berjaringan (X1.5)

Kinerja penyuluh memotivasi dan memfasilitasi petani menjalin kerjasama dalam dan atar kelompok tani, serta dengan kelembagaan agribisnis lain dalam program peningkatan produksi sapi potong.

6. Kaderisasi (X1.6)

Kinerja penyuluh menumbuhkan kader-kader petani untuk pendampingan dan mendampingi kader jika menemui kesulitan dalam program peningkatan produksi sapi potong.

\section{Sumber Daya Manusia pada Optimalisai IB} (X2)

Indikator variable sumber daya manusia pada optimalisasi IB (Inseminasi Buatan) meliputi : pelatihan, pengalaman peternak dan sosialisasi pekerjaan (Individu/Kelompok). Sinaga (2009), Wibowo, Guntoro dan Sulastri (2011)

1. Pelatihan pada optimalisai IB (Inseminasi Buatan) (X2.1)

Interval pelaksanaan program Pelatihan pada optimalisai IB (Inseminasi Buatan) yang pernah diikuti dari lembaga pemerintah / non pemerintah pada peningkatan produksi sapi potong.

2. Pengalaman petani ternak sapi potong (X2.2) 
Berdasarkan pengalaman petani ternak sapi potong pada optimalisasi IB dalam peningkatan produksi sapi potong.

3. Sosialisasi Program (Individu / Kelompok) (X2.3)

Kegiatan sosialisasi pekerjaan (Individu / Kelompok) yang dilakukan petugas IB dengan petani ternak dalam peningkatan produksi sapi potong

\section{Sarana Prasarana Perluasan Lahan HMT (X3)}

Indikator dari variable sarana pra-sarana perluasan lahan HMT (Hijauan Makanan Ternak) meliputi : luas lahan, Sarana produksi (bibit,pupuk, obat-obatan), Ketersediaan tenaga kerja dan

Persediaan modal. (Soetriono et al 2006).

1. Luas lahan HMT (Hijauan Makanan Ternak) (X3.1)

Kebutuhan luas lahan yang digunakan pada perluasan HMT tercukupi dalam mendukung peningkatan produksi sapi potong.

2. Sarana produksi (bibit unggul, pupuk, obatobatan) (X3.2)

Kebutuhan sarana produksi (bibit unggul, pupuk, obat-obatan) yang digunakan pada perluasan HMT tercukupi dalam peningkatan produksi sapi potong.

3. Ketersediaan tenaga kerja (X3.3)

Kebutuhan ketersediaan tenaga kerja yang digunakan pada perluasan HMT tercukupi dalam peningkatan produksi sapi potong.

4. Persediaan modal (X3.4)

Kebutuhan persediaan modal yang digunakan pada perluasan HMT tercukupi dalam peningkatan produksi sapi potong.

\section{Produksi Sapi Potong (Y1)}

Indikator variable peningkatan sapi potong meliputi : populasi ternak, swasembada daging dan jumlah kelahiran hasil IB. (Tawaf dan Kuswaryan 2006).

1. Populasi ternak (Y1.1) Populasi ternak mengalami peningkatan melalui program peningkatan produksi sapi potong.

2. Swasembada daging (Y1.2)

Swaswmbada daging mengalami peningkatan melalui program peningkatan produksi sapi potong.

3. Jumlah kelahiran hasil IB (Inseminasi Buatan) ((Y1.3)

Jumlah kelahiran hasil IB (Inseminasi Buatan) mengalami peningkatan melalui program peningkatan produksi sapi potong.

Analisis yang digunakan untuk menguji hipotesis dalam penelitian ini adalah model persamaan struktural (Structural Equation Modeling atau SEM) dengan menggunakan paket program AMOS (Analysis of Moment Structure) versi 18. Model persamaan struktural (SEM) adalah metode analisis yang digunakan dalam penelitian ini. Dalam SEM, ada dua kelompok analisis yang dilakukan secara bertahap, yaitu: (a) model pengukuran (measurement model) dan (b) model struktural (structural model). Secara umum, ada dua alat analisis utama dalam penelitian ini, yaitu: 1) alat uji asumsi SEM, dan 2) alat uji kecocokan model. Uji data yang telah terbukti valid dan reliabel pada tahap uji sebelumnya, dilakukan melalui ukuran-ukuran normalitas data secara univariat atau multivariat, Outlier (data yang berada di luar sebaran sebagian besar data), baik secara univariat maupun multivariat dan multikolinieritas. Beberapa uji goodness-of-fit model overall bersama dengan nilai cut-off-nya dapat dilihat pada Tabel 1.

Tabel 1 Pengujian goodness of fit model overall

\begin{tabular}{ccc}
\hline Kriteria & Nilai Cut-Off & Keterangan \\
\hline Chi Square & Diharapkan kecil. & Good Fit \\
Pignificance & $\geq 0,05$ & Good Fit \\
Probability & $\leq 0,08$ & Good Fit \\
RMSEA & $\geq 0,90$ & Good Fit \\
GFI & $\geq 0,90$ & Good Fit \\
AGFI & $\leq 2$ atau 3 & Good Fit \\
CMIN/DF & $\geq 0,90$ & Good Fit \\
TLI & $\geq 0,90$ & Good Fit \\
CFI &
\end{tabular}

Sumber: Ferdinand (2006)

\section{HASIL DAN PEMBAHASAN}

Evaluasi asumsi SEM ini dibedakan atas empat macam, yaitu: ukuran sampel, uji outliers, uji normalitas dan multikolinieritas.

\section{a. Ukuran sampel}

Pemodelan SEM ukuran sampel yang harus dipenuhi untuk Maximum Likelihood estimation (MLE) yaitu 100-200 (Ferdinan 2002). Penelitian ini menggunakan sampel $(10 \times 16$ indikator) berarti jumlah sampel $10 \times 16=160$ sampel. Jumlah sampel sebanyak 160 diperoleh dari petani ternak sapi potong di kabupaten Bondowoso. Sehingga penelitian ini sudah memenuhi asumsi jumlah sampel.

\section{b. Hasil uji outlier}

Hasil uji outliers pada penelitian nampak pada Malahanobis distance atau Mahalanobis $d$ squared. Dalam menghitung nilai Malahanobis distance berdasarkan nilai Chi squares pada derajat bebas 16 (jumlah variabel indikator) pada tingkat $p<0,05\left(\chi^{2} 16,0,05\right)$ (Ghozali 2008), adalah sebesar 78.860. Jadi data yang memiliki jarak Mahalnobis Distance lebih besar dari 78.860 
Niken Dyah Ayu KD, Rizal dan Hariadi S, Analisis Program Penyuluhan, Sumber Daya Manusia Pada Optimalisasi IB Dan Sarana Prasarana Perluasan Lahan HMT Terhadap Peningkatan Produksi Sapi Potong Di Kabupaten Bondowoso

adalah Multivariate Outlier. Hasil Uji Outlier menunjukan bahwa nilai tertinggi sebesar 40,947 sehingga tidak ada kasus yang memiliki nilai Mahalnobis Distance lebih besar dari 48,159. Sehingga dapat disimpulkan tidak ada Multivariate Outlier dalam data penelitian

\section{c. Uji normalitas}

Uji normalitas perlu dilakukan baik untuk normalitas terhadap data univariat maupun NormalitasMultivariate dimana beberapa variabel yang digunakan sekaligus dalam analisis akhir. Untuk menguji dilanggar/tidaknya asumsi normalitas, maka dapat dilakukan dengan menggunakan nilai statistik z untuk Skewness dan kurtosisnya dan secara empirik dapat dilihat pada Critical Ratio (CR). Jika digunakan tingkat signifikansi $0,05(5 \%)$, maka nilai $\mathrm{CR}$ yang berada diantara $-1,96$ dan $1,96(-1,96 \leq \mathrm{CR} \leq$ 1,96) dikatakan data berdistrbusi normal baik secara Univariat maupun Multivariat. Hasil pengujian normalitas atau Assessment of Normality memberikan nilai CR sebesar -1,246 yang terletak diantara $(-1,96 \leq \mathrm{CR} \leq 1,96$ pada error $(\alpha=0,05)$, sehingga dapat dikatakan bahwa data multivariate normal. Selain itu juga data univariat normal ditunjukan oleh semua nilai Critical Ratio semua indikator diantara $(-1,96 \leq$ $\mathrm{CR} \leq 1,96)$

\section{d. Multikolinieritas}

Ghozali (2008) mentampaikan bahwa Multikolinieritas dapat dilihat melalui determinan matriks kovarians. Nilai determinan yang sangat kecil atau mendekati nol, menunjukan indikasi terdapatnya masalah multikoliniaritas atau singularitas. Hasil pengujian memberikan nilai Determinant of Sample Covariance Matrix sebesar 7,373. Nilai ini menjauhi dari angka nol sehingga dapat simpulkan bahwa data tidak terdapat masalah multikolinieritas dan singularitas pada data yang dianalisis.

Model persamaan struktural yang dihasilkan dengan aplikasi Program AMOS versi 18.00, adalah dengan menganalisis konstruk eksogen terhadap konstruk endogennya secara simultan. Seluruh indikator variabel yang terbukti valid diatas 0,50 dan reliabel diatas 0,70 sehingga model dapat digunakan untuk analisis, seperti disajikan pada Gambar 2.

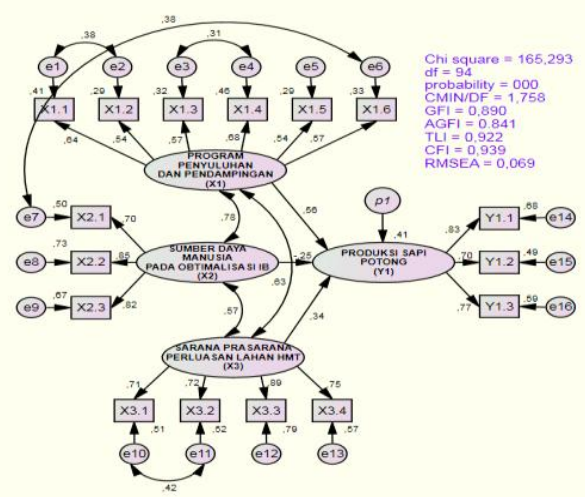

Gambar 2 CFA SEM (Structural Equation Modeling)

Hasil pengujian SEM diperoleh nilai goodness of fit model overall disajikan pada tabel 2.

\begin{tabular}{lccc}
\hline Kriteria & $\begin{array}{c}\text { Nilai Cut } \\
\text { Off }\end{array}$ & $\begin{array}{c}\text { Hasil } \\
\text { Perhitungan }\end{array}$ & Keterangan \\
\hline Chi square & $\begin{array}{c}\text { Diharapkan } \\
\text { lebih kecil } \\
190,165\end{array}$ & 165,293 & Good Fit \\
$\begin{array}{l}\text { Significane } \\
\text { Probality }\end{array}$ & $\geq 0,05$ & 0,00 & Marginal Fit \\
RMSEA & $\leq 0,08$ & 0,069 & Good Fit \\
GFI & $\geq 0,90$ & 0,89 & Marginal Fit \\
AGFI & $\geq 0,90$ & 0,84 & Marginal Fit \\
CMIN/DF & $\leq 2,00$ & 1,75 & Good Fit \\
TLI & $\geq 0,90$ & 0,92 & Good Fit \\
CFI & $\geq 0,90$ & 0,93 & Good Fit \\
\hline
\end{tabular}

Tabel 2 Hasil uji Indeks kesesuaian model

Hasil pengujian hipotesis dari model SEM dapat disajikan Tabel 3.

\begin{tabular}{|c|c|c|c|c|c|c|}
\hline Variabel / Ind & likator & Penelitian & $\begin{array}{c}\text { Koefisien } \\
\text { Jalur }\end{array}$ & CR & $\begin{array}{l}\text { Proba } \\
\text { bilitas }\end{array}$ & Ket. \\
\hline $\begin{array}{l}\text { PROGRAM } \\
\text { PENYULUH } \\
\text { AN DAN } \\
\text { PENDAMPI } \\
\text { NGAN } \\
(\mathrm{X} 1)\end{array}$ & $--->$ & $\begin{array}{l}\text { PRODUK } \\
\text { SI SAPI } \\
\text { POTONG } \\
(\mathrm{Y} 1)\end{array}$ & 0,556 & $\begin{array}{l}2,5 \\
50\end{array}$ & $\begin{array}{l}0,0 \\
11\end{array}$ & $\begin{array}{c}\text { Signif } \\
\text { ikan }\end{array}$ \\
\hline $\begin{array}{l}\text { SUMBER } \\
\text { DAYA } \\
\text { MANUSIA } \\
\text { PADA } \\
\text { OBTIMALIS } \\
\text { AI IB } \\
(\mathrm{X} 2) \\
\end{array}$ & $-->$ & $\begin{array}{l}\text { PRODUK } \\
\text { SI SAPI } \\
\text { POTONG } \\
(\mathrm{Y} 1)\end{array}$ & 0,251 & $\begin{array}{c}- \\
1,3 \\
99\end{array}$ & $\begin{array}{l}0,1 \\
62\end{array}$ & $\begin{array}{c}\text { Non } \\
\text { Signif } \\
\text { ikan }\end{array}$ \\
\hline $\begin{array}{l}\text { SARANA } \\
\text { PRASARAN } \\
\text { A } \\
\text { PERLUASA } \\
\text { N LAHAN } \\
\text { HMT } \\
\text { (X3) }\end{array}$ & $--->$ & $\begin{array}{l}\text { PRODUK } \\
\text { SI SAPI } \\
\text { POTONG } \\
(\mathrm{Y} 1)\end{array}$ & 0,342 & $\begin{array}{l}2,7 \\
16\end{array}$ & $\begin{array}{l}0,0 \\
07\end{array}$ & $\begin{array}{c}\text { Signif } \\
\text { ikan }\end{array}$ \\
\hline
\end{tabular}

Tabel 3 Hasil uji kausalitas penelitian

Keterangan : Hasil analisis SEM 
Pengujian hipotesis merupakan pembuktian atas variabel yang telah diajukankan dalam penelitian. Berdasarkan hasil analisis data menggunakan Sructural Equation Modeling (SEM), pengujian hipotesis dilakukan dengan menganalisis Critical Ratio (CR) dan nilai Probabilitas $(\mathrm{P})$ hasil analisis data dibandingkan dengan batasan yang disyaratkan dapat diterima jika pada taraf signifikan 0,05 Probabilitas ( $\mathrm{P}<$ 0,05) dan nilai Critical Ratio (CR > 2,00). Jadi apabila hasil dari interprestasi data dikatakan memenuhi persyaratan tersebut maka hipotesis dalam penelitian yang diajukan dinyatakan dapat diterima. Berdasarkan hasil interpretasi masingmasing koefesien jalur adalah sebagai berikut :

H1 : Program penyuluhan dan pendampingan bagi petani ternak berpengaruh positif signifikan terhadap peningkatan produksi sapi potong di Kabupaten Bondowoso. Parameter estimasi menunjukkan nilai koefisien sebesar 0,556 nilai probabilitas sebesar 0,011 dan nilai CR sebesar 2,550. Sedangkan yang dapat diterima pada taraf signifikan 0,05 adalah nilai Probabilitas $(\mathrm{P}$ $<0,05)$ dengan nilai Critical Ratio (CR > 2,00). Hal ini berarti bahwa Program penyuluhan dan pendampingan bagi petani ternak berpengaruh positif signifikan terhadap peningkatan produksi sapi potong di Kabupaten Bondowoso. Dengan demikian hipotesis pertama dapat dibuktikan kebenarannya (diterima).

H2 : Sumber Daya Manusia pada Optimalisai IB berpengaruh positif signifikan terhadap peningkatan produksi sapi potong di Kabupaten Bondowoso. Parameter estimasi menunjukkan nilai koefisien sebesar -0,251 nilai probabilitas sebesar 0,162 dan nilai CR sebesar $-1,1399$. Sedangkan yang dapat diterima pada taraf signifikan 0,05 adalah nilai Probabilitas $(\mathrm{P}<0,05)$ dengan nilai Critical Ratio (CR > 2,00). Hal ini berarti bahwa Sumber Daya Manusia pada Optimalisai IB tidak berpengaruh positif signifikan terhadap peningkatan produksi sapi potong di Kabupaten Bondowoso. Dengan demikian hipotesis kedua tidak dapat dibuktikan kebenarannya (ditolak).

H3 : Sarana Pra-sarana Perluasan Lahan HMT berpengaruh positif signifikan terhadap peningkatan produksi sapi potong di Kabupaten Bondowoso. Parameter estimasi menunjukkan nilai koefisien sebesar 0,342 nilai probabilitas sebesar 0,007 dan nilai CR sebesar 2,716. Sedangkan yang dapat diterima pada taraf signifikan 0,05 adalah nilai Probabilitas $(\mathrm{P}<0,05)$ dengan nilai
Critical Ratio (CR > 2,00). Hal ini berarti bahwa Sarana Pra-sarana Perluasan Lahan HMT berpengaruh positif signifikan terhadap peningkatan produksi sapi potong di Kabupaten Bondowoso. Dengan demikian hipotesis ketiga dapat dibuktikan kebenarannya (diterima).

Berdasarkan pengujian hipotesis diperoleh hasil bahwa variabel penelitian yang berpengaruh positif signifikan terhadap peningkatan produksi sapi potong di Kabupaten Bondowoso adalah : (H1) Program penyuluhan dan pendampingan bagi petani ternak; dan (H3) Pra-sarana Perluasan Lahan HMT. Sedangkan variabel penelitian yang tidak berpengaruh positif signifikan terhadap peningkatan produksi sapi potong di Kabupaten Bondowoso adalah (H3) Sumber Daya Manusia pada Optimalisai IB.

\section{Implikasi Manajerial}

Penelitian ini memiliki implikasi manajerial bagi pengambil kebijakan dalam upaya meningkatkan produksi sapi potong, yaitu melalui tiga pendekatan antara lain:

1. Mempertahankan program penyuluhan dan pendampingan pada petani ternak sapi potong yang diprioritaskan pada indikator yang paling dominan adalah program penguatan partisipasi petani ternak sapi potong dengan petugas IB (Inseminasi Buatan). Hal ini membuktikan adanya kerja sama yang baik antara petani ternak sapi potong dengan petugas dalam hal ketepatan waktu mengkoordinasikan saat ternak sapi birahi yang segera harus dilakukan inseminasi buatan, pengendalian dan pengobatan penyakit pada ternak terutama penyakit menular. maka dalam jangka panjang akan berdampak secara signifikan terhadap jumlah kelahiran hasil IB (inseminasi buatan). Sehingga dapat meningkatkan secara singnifikan terhadap peningkatan produksi sapi potong yang diidikasikan pada indikator Jumlah populasi ternah yang nantinya dapat memenuhi swasembada daging.

2. Menunjang fasilitas sarana prasarana perluasan HMT yang diprioritaskan pada indikator yang paling dominan adalah ketersediaan dan kemudahan akses saran prasaran yang dibutuhkan tenaga kerja. Hal ini membuktikan sumber daya ketenagakerjaan yang berkecukupan dapat menunjang proses produksi pengembangan hijauan makanan ternak. Secara tidak langsung ketersediaan tenaga kerja dengan jumlah yang cukup bukan hanya dilihat dari ketersediaannya tetapi juga kualitas tenaga 
Niken Dyah Ayu KD, Rizal dan Hariadi S, Analisis Program Penyuluhan, Sumber Daya Manusia Pada Optimalisasi IB Dan Sarana Prasarana Perluasan Lahan HMT Terhadap Peningkatan Produksi Sapi Potong Di Kabupaten Bondowoso

kerja. Jumlah tenaga kerja banyak dipengaruhi dan dikaitkan dengan upah tenaga kerja yang konsisten dengan upah minimal regional, maka dalam jangka panjang peluasan lahan HMT dapat memenuhi kebutuhan pakan ternak yang bekecukupan terhadap kebutuhan pupulasi ternak yang ada sejalan dengan meningkatnya jumlah kelahiran hasil IB (inseminasi buatan).

3. Meningkatkan kompetensi sumber daya manusia pada optimalisasi IB (Inseminasi Buatan) yang diprioritaskan pada indikator yang paling dominan adalah tingkat pengalaman petani ternak sapi potong dalam hal kemampuan mengidentifikasi ketepatan waktu pelaksanaan inseminasi serta pengalaman dalam mendeteksi adanya gejala penyakit yang menular. Peningkatan kemampuan dapat dilakukan dengan program pelatihan yang intensif, maka dalam jangka panjang dengan meningkatkan kemampuan petani ternak sapi potong dalam mengidentifikasi kegagalan-kegalan berdasarkan pengalaman akan berdampak terhadap peningkatan jumlah kelahiran hasil IB (inseminasi buatan) yang berdampak pada populasi ternak yang diharapkan memenuhi swasembaga daging.

\section{SIMPULAN DAN SARAN Simpulan}

Penelitian analisis engaruh program penyuluhan, sember daya manusia ptimalisasi IB dan sarana prasarana perluasan lahan HMT terhadap peningkatan produksi sapi potong di Kabupaten Bondowoso disimpulkan sebagai berikut:

1. Program penyuluhan dan pendampingan bagi petani ternak berpengaruh positif signifikan terhadap peningkatan produksi sapi potong di Kabupaten Bondowoso. Membuktikan bahwa hipotesis penelitian (diterima). Program penyuluhan yang paling dominan adalah penguatan partisipasi petani ternak sapi potong dengan petugas IB (Inseminasi Buatan). Sedangkan peningkatan produksi sapi yang paling dominan adalah jumlah populasi ternak sapi. Pengaruh secara langsung dititikberatkan pada kemampuan petani ternak dalam mengidentifikasi ketepatan pelaksanaan iseminasi dan mendektesi gejala penyakit menular sehingga secara tidak langsung dalam jangka panjang dapat meningkatkan jumlah angka kelahiran hasil inseminasi yang berdampak pada peningkatan pupulasi ternak dalam rangka pencapaian swasembada daging.
2. Sumber daya manusia pada optimalisasi IB (Inseminasi Buatan) tidak berpengaruh positif signifikan terhadap peningkatan produksi sapi potong di Kabupaten Bondowoso. Membuktikan bahwa hipotesis penelitian (ditolak). Sumber daya manusia yang paling dominan adalah tingkat pengalaman petani ternak sapi potong dalam hal kemampuan mengidentifikasi ketepatan waktu pelaksanaan inseminasi serta pengalaman dalam mendeteksi adanya gejala penyakit yang menular. Sedangkan peningkatan produksi sapi yang paling dominan adalah jumlah populasi ternak sapi. Pengaruh secara langsung dampak dari kurangnya pengalaman dan kemampuan petani ternak memperikan respon negatif secara signifikan terhadap jumlah angka kelahiran hasil IB. Serta secara tidak langsung dalam jangka panjang dapat berdampak pada jumlah pupulasi ternak serta dapat menjadi menghambat pencapaian swasembada daging.

3. Sarana pra-sarana perluasan lahan HMT (Hijauan Makanan Ternak) berpengaruh positif signifikan terhadap peningkatan produksi sapi potong di Kabupaten Bondowoso. Membuktikan bahwa hipotesis penelitian (diterima). Fasilitas sarana prasarana perluasan lahan HMT yang paling dominan adalah ketersediaan tenaga kerja yang didukungoleh fasilitas saran prasarana Infrastruktur, transportasi, sistem upah tenaga kerja. Sehingga secara langsung kebutuhan tenaga kerja dalam perluasan HMT memberikan kecukupan pada kebutuhan pakan ternak ternak sapi potong. Sedangkan peningkatan produksi sapi yang paling dominan adalah jumlah populasi ternak sapi. Pengaruh secara langsung dengan kecukupan julahpakan denga jumlah populasi sapi potong dalam jangka panjang dapat menunjang pencapaian swasembada daging.

\section{Saran}

Penelitian mengenai analisis engaruh program penyuluhan, sember daya manusia ptimalisasi IB dan sarana prasarana perluasan lahan HMT terhadap peningkatan produksi sapi potong masih memungkinkan untuk dikembangkan sehingga lebih dapat digeneralisasikan, antara lain:

1. Saluran distribusi rantai pasok ternak sapi potong.

2. Peningkatan rantai nilai ternak sapi potong. 


\section{DAFTAR PUSTAKA}

[DPP] Dinas Peternakan dan Perikanan. 2010. Laporan Akuntabilitas Kinerja Instansi Pemerintah Kabupaten Bondowoso: (ID). 2011. Laporan Akuntabilitas Kinerja Instansi Pemerintah Kabupaten Bondowoso: (ID).

2012. Laporan Akuntabilitas Kinerja Instansi Pemerintah Kabupaten Bondowoso: (ID).

[DEPTAN) Departemen Pertanian. 2005. Rencana aksi pemantapan ketahanan pangan 2005 2010. Badan Peneliti dan Pengembangan Pertanian. Republik Indonesia. (ID).

[DITJEN] Peternakan dan Kesehatan Hewan. 2012. Press Release Konfrensi Pers Direktur Jenderal Peternakan Dan Kesehatan Hewan tentang supply demand daging sapi dan kerbau sampai dengan Desember 2012. Indonesia. (ID).

Ferdinand A. 1999. Strategic pathways toward sustainable competitive advantage. Unpublised DBA [tesis]. Australia (AU): Shouthern Cross Lismore.

2000. Manajemen Pemasaran, Sebuah Pendekatan Stratejik. Research Paper Series Magister Managemen. Semarang (ID): Badan Penerbit Undip.

2002. Structural Equation Modeling dalam Penelitian Manajemen. Semarang (ID): Badan Penerbit Undip.

Ghozali I. 2005. Aplikasi Amos Versi 16.0. Jakarta (ID): PT Gramedia.

2008. Amos Versi 21.0. Semarang (ID): Badan Penerbit Undip.

Hastuti D. 2008. Tingkat keberhasilan inseminasi buatan sapi potong ditinjau dari angka konsepsi dan service per conception. Indonesia: (ID). J. Mediagro. 4(1):12- 20.

Herawati T, Anggraeni A, Praharani L, Utami D, Argiris A. (2012). Peran inseminator dalam keberhasilan inseminasi buatan pada sapi perah . J. Informatika Pertanian. 21(2).

Kementerian Pertanian, 2012. Laporan akuntabilitas kinerja Kementerian Pertanian 2011. Republik Indonesia: (ID).

Khalid MM et al. 2012. Propsing a training evaluation strategy to ensure training transfer in public sector organizations in pakistan: (PKT). International Journal of Human Resource Studies. 2(1):21623058.

King, Joyce Ann. 2008. An evaluation of a character education program at an elementary school [disertation]. Southeastern: (SOUT). Nova Southeastern University.
Marliati, Sumardjo, Asngari PS, Tjiptopronoto, Saefuddin A. 2008. Faktor-faktor penentu peningkatan kinerja penyuluh pertanian dalam memberdayakan petani di Kabupaten Kampar Provinsi Riau. (ID). Jurnal Penyuluhan. 4(2).

Maryamsari I, Mujiburrahmad. 2012. Karakteristik petani dan hubungannya dengan kompetensi petani lahan sempit di Desa Sinar Sari Kecamatan Dramaga Kabupeten Bogor Jawa Barat. (ID). J Agrisep. 15(2).

Okkyla S, Isbandi, Samsudewa D. 2013. Hubungan motivasi dengan perilaku dalam pemanfaatan teknologi inseminasi buatan pada peternak anggota kelompok tani ternak sapi perah (Studi Kasus di Kecamatan Ungaran Barat Kabupaten Semarang): (ID). Animal Agricultural Journal. 2(2):1-7.

Rustijarno S, Sudaryanto B. 2006. Peningkatan ketahanan pangan melalui kecukupan daging sapi 2010. hlm. 66-374. Dalam B. Suryanto, Isbandi, B.S. Mulayatno, B. Sukamto, E. Rianto, dan A.M. Legowo (Ed.). Pemberdayaan Masyarakat Peternakan di Bidang Agribisnis untuk Mendukung Ketahanan Pangan. Prosiding Seminar Nasional 2006, Semarang: (ID). Universitas Diponegoro.

Situmorang P, Gede IP. 2003. Peningkatan efisiensi reproduksi melalui perkawinan alam dan pemanfaatan inseminasi buatan [IB] untuk mendukung program pemuliaan; Lokakarya Sistem Integrasi Kelapa Sawit dengan Sapi.

Siagian SP. 2000. Manjemen Sumber Daya Manusia. Ed ke-1. Jakarta (ID): Bumi Aksara

Tawaf R, Kuswaryan S. 2006. Kendala Kecukupan Daging 2010. di dalam; Prosiding Seminar Nasional Pemberdayaan Masyarakat Peternakan di Bidang Agribisnis untuk Mendukung Ketahanan Pangan. Semarang, (ID). 3 Agustus 2006. 